\title{
Sustainable Approach for University Ranking System
}

\author{
Shahab Saquib Sohail ${ }^{1}$, Jamshed Siddiqui ${ }^{2}$, Shakil $^{3}$, Mohammed Talha Alam ${ }^{4}$, Syed Ubaid ${ }^{5}$, \\ Jawed Ahmed ${ }^{6}$, M. Afshar Alam ${ }^{7}$ \\ $\left\{{ }^{1}\right.$ shahabsaquibsohail@gmail.com, ${ }^{2}$ jamshed_faiza@ $@$ rediffmail.com, ${ }^{3}$ shakilsaifiyz88@ gmail.com, ${ }^{4}$ \\ talha.alam444@gmail.com, ${ }^{5}$ syedubaid477@gmail.com, ${ }^{6}$ jawed2047@gmail.com, \\ 7aalam@jamiahamdard.ac.in \}
}

\author{
1,3,4,5,6,7epartment of Computer Science and Engineering, Jamia Hamdard, New Delhi, \\ India.
}

${ }^{2}$ Department of Computer Science, Aligarh Muslim University, India

\begin{abstract}
In this paper we observe various university ranking system to find the most desirable university worldwide. The primary objective of this article is to present a framework of proposed ranking system which contains the most valuable features of the top five world university ranking systems which helps students and scholars to sharpen the result for their idealised university. A better ranking system approach is shownwhich comprises all the best features of the existing top university ranking system.
\end{abstract}

Keywords: Ranking method; sustainability; university ranking; soft computing

\section{Introduction}

We have observed a tremendous increase in methods for comparing and ranking universities around the globe lately. It can be witnessed by the increasing figure of yearly rankings being published in addition to the number of conferences being held on the topic. Higher education institutions use these rankings as a publicity tool that determines their educational, research or business quality. There are millions of visitors every year to the rankings' websites and many aspirant scholars use them as a guide for deciding which institutions to join $[1,2]$. Ranking systems are precisely concerned with excellence. This article asks what constitutes excellence in a university, and how each criterion of excellence are to be selected and scaled. We then observe some of the bestknown international ranking systems - the Times Higher Education Supplement (THES) system, QS World University Ranking, Academic Ranking of World Universities (ARWU), US News Ranking and Round University Rankings. A significant interpretation of these methods will highlight an extensive range of criteria that international ranking systems can operate and grants an opportunity for assessing these criteria. In this paper, we put forward a new ranking system which considers all the criteria with maximum weights in the above mentioned ranking systems and inculcates them in our proposed ranking system by 
establishing a correlation between our proposed rankings and the ranking mentioned by some of the best known international ranking systems.

\section{University Ranking System}

Rankings are usually conducted by the basic source of knowledge like websites etc. University rankings are used to rank higher education institutions according todifferent criteria. No ranking approach provides a full sketch of potency of the institutions ranked because approaches choose an area of easily calculable characteristics for their results.For ranking whole institutions, organizations make rankings of particular programs and faculty. Different rankings approaches recognise orders of measures ofresearch works, citations, students, awards, international outlook, graduate employment, industrial linkage, teachers, historical reputation and other criteria. Ranking approaches ordinarily evaluate institutional result by research. Some systems work in a single country, and others internationally.[3, 7, 8].

\subsection{Background}

Education of higher-level is raised after $1900 \mathrm{AD}$ and more demand for higher education has risen to the growth and success of higher education ranking systems which help to figure out higher education institutions according to their needs. These ranking system develops competition between higher education institutions for creating their standards in different countries. The impact of global approaches can barely be dropped. Approaches affect the views and choices of many universities administrators and teachers, considered students, state policymakers and governors, and industry. Highly ranked institutions are better as they are productive, provide higher-quality teaching and research, and give better results to the community than lower-ranked organizations. The ranking system is oftentimes used as promotion for universities, permitting them to face globally for financial and human resources. It acts like a tool that paves way for university perfection. The number of ranking system has increasedover the years. The top 3 biggest and prominent ranking systems arethe Times Higher Education (THE) world university rankings, the Quacqarelli-Symonds (QS) rankings and the Academic Ranking of World Universities (ARWU).[4, 20]

\subsection{Existing Ranking System}

We have the various ranking system available on the internet to find an ideal institute globally. we are showing the best five ranking systems which work universally are QS, ARWU, Times higher, Round and US. News.

QS world university ranking is once a year writing of university ranking. QS stands for Quacquarelli Symonds. QS is in partnership with The Higher Education in 2004 for their first ranking table but in 2010 it makes its own separated version. It evaluated universities based on six matrices: Academic Reputation, Employer Reputation, Faculty/Student Ratio, Citations per faculty, International Faculty Ratio, International Student Ratio [5, 13].

Times Higher Education Ranking(THE) is developed in 2004 with QS ranking but it broke the contract with QS in 2010 and develop a new methodology with different standards. The first ranking according to THE was declared in September 2010. It is also a yearly world university 
ranking. Its methodology contains five overall criteria: Teaching, Research, Citations, Industry income and International outlook [4][5].

Academic ranking world universities(ARWU), also have another name as Shanghai Ranking, is one of the every year announcement of world university ranking. The league table became the first global university ranking with multifarious indicators and was issued in shanghai university. ARWU has four criteria: Quality of faculty, Research Output, Per Capita Performance and Quality of Education [6, 16].

Round university ranking (RUR) is a globally using university ranking system. RUR ranking publisher is located in Moscow, Russia. This ranking also publishes World University ranking every year. RUR methodology contains four criteria: Teaching, Research, International Diversity and Financial Sustainability [7, 20].

U.S. News \& World Report is a media company of America that publishes news and world ranking of universities. U.S. News is best noted today for its Fittest Colleges rankings. Since 1987 this ranking has compiled and published annually. U.S. News methodology work on thirteen indicators: Global research reputation, Regional research reputation, Publications, Books, Conferences, Normalized citation impact, Total citations, Number of publications that are among the $10 \%$ most cited, Percentage of total publications that are among the $10 \%$ most cited, Number of highly cited papers that are among the top $1 \%$ most cited in their respective field, Percentage of total publications that are among the top $1 \%$ most highly cited papers, International collaboration - relative to country and International collaboration. $[9,10,18]$.

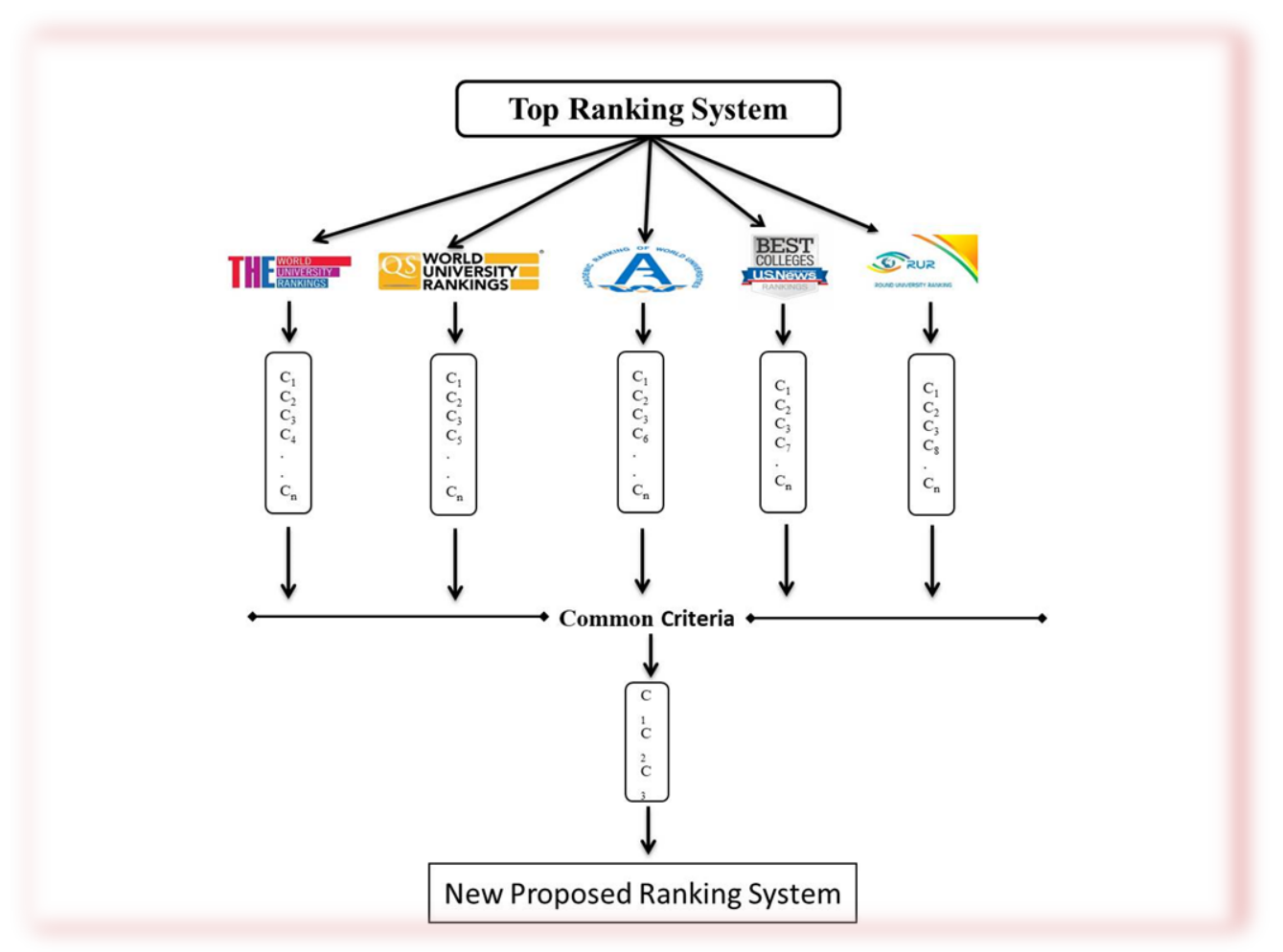

Figure 1: Architecture for university ranking approach 
Table 1: Top five universities according to different ranking systems.[11][12][13][14][15]

\begin{tabular}{|c|c|c|c|c|c|}
\hline $\begin{array}{l}\text { Sl. } \\
\text { No. }\end{array}$ & QS ranking & $\begin{array}{l}\text { Times Higher } \\
\text { Education }\end{array}$ & ARWU & US News & Round \\
\hline 1 & $\begin{array}{ll}\text { Massachusetts } & \text { Institute } \\
\text { Technology(MIT) } & \end{array}$ & $\begin{array}{l}\text { University of } \\
\text { Oxford }\end{array}$ & Harvard University & $\begin{array}{l}\text { Harvard } \\
\text { University }\end{array}$ & $\begin{array}{l}\text { Harvard } \\
\text { University }\end{array}$ \\
\hline 2 & Stanford University & $\begin{array}{l}\text { California Institute } \\
\text { of Technology } \\
\text { (Caltech) }\end{array}$ & $\begin{array}{l}\text { Stanford } \\
\text { University }\end{array}$ & $\begin{array}{l}\text { Massachusetts } \\
\text { Institute of } \\
\text { Technology(MIT) }\end{array}$ & $\begin{array}{l}\text { California } \\
\text { Institute of } \\
\text { Technology } \\
\text { (Caltech) }\end{array}$ \\
\hline 3 & Harvard University & $\begin{array}{l}\text { University of } \\
\text { Cambridge }\end{array}$ & $\begin{array}{l}\text { University of } \\
\text { Cambridge }\end{array}$ & $\begin{array}{l}\text { Stanford } \\
\text { University }\end{array}$ & $\begin{array}{l}\text { Imperial } \\
\text { College } \\
\text { London }\end{array}$ \\
\hline 4 & University of Oxford & $\begin{array}{l}\text { Stanford } \\
\text { University }\end{array}$ & $\begin{array}{l}\text { Massachusetts } \\
\text { Institute of } \\
\text { Technology(MIT) }\end{array}$ & $\begin{array}{l}\text { University of } \\
\text { California, } \\
\text { Berkeley }\end{array}$ & $\begin{array}{l}\text { Stanford } \\
\text { University }\end{array}$ \\
\hline 5 & California Institute of Technology(Caltech) & $\begin{array}{l}\text { Massachusetts } \\
\text { Institute of } \\
\text { Technology(MIT) }\end{array}$ & $\begin{array}{l}\text { University } \\
\text { California, } \\
\text { Berkeley }\end{array}$ & $\begin{array}{l}\text { University of } \\
\text { Oxford }\end{array}$ & $\begin{array}{l}\text { Yale } \\
\text { University }\end{array}$ \\
\hline
\end{tabular}

Table 2: No. of criteria of top university ranking systems.[11][12][13][14][15].

\begin{tabular}{lccccc}
\hline Ranking System & QS & $\begin{array}{l}\text { Times Higher } \\
\text { Education }\end{array}$ & ARWU & U.S. News & Round \\
\hline No of Criteria & 6 & 5 & 6 & 13 & 20 \\
\hline
\end{tabular}




\section{Sustainable Appoach for University Ranking System}

We have simplified the method of recommendation and would like to incorporate all the best ranking together. By this we can easily aggregate these ranking and best of them can represented. The Fig. 1 represents the already existing ranking system and their top ranked universities which has been tabulated in table 1 . Table 2 shows the number of criteria they are using for their ranking process. In the table 3 below, we have tried to show how the aggregation of these ranking with the help of different scoring can be done $[1,7,8,13,19]$.

The Fig. 2 is a proposed framework for getting the best universities from the ranking system which has been explained using Table 2 . We believe the proposed meyhod can lead a better way of framing the ranking system which would eventually help to the several leading ranking methodologies that includes Times higher education, QS ranking, NIRF ranking by Govt. of India etc.

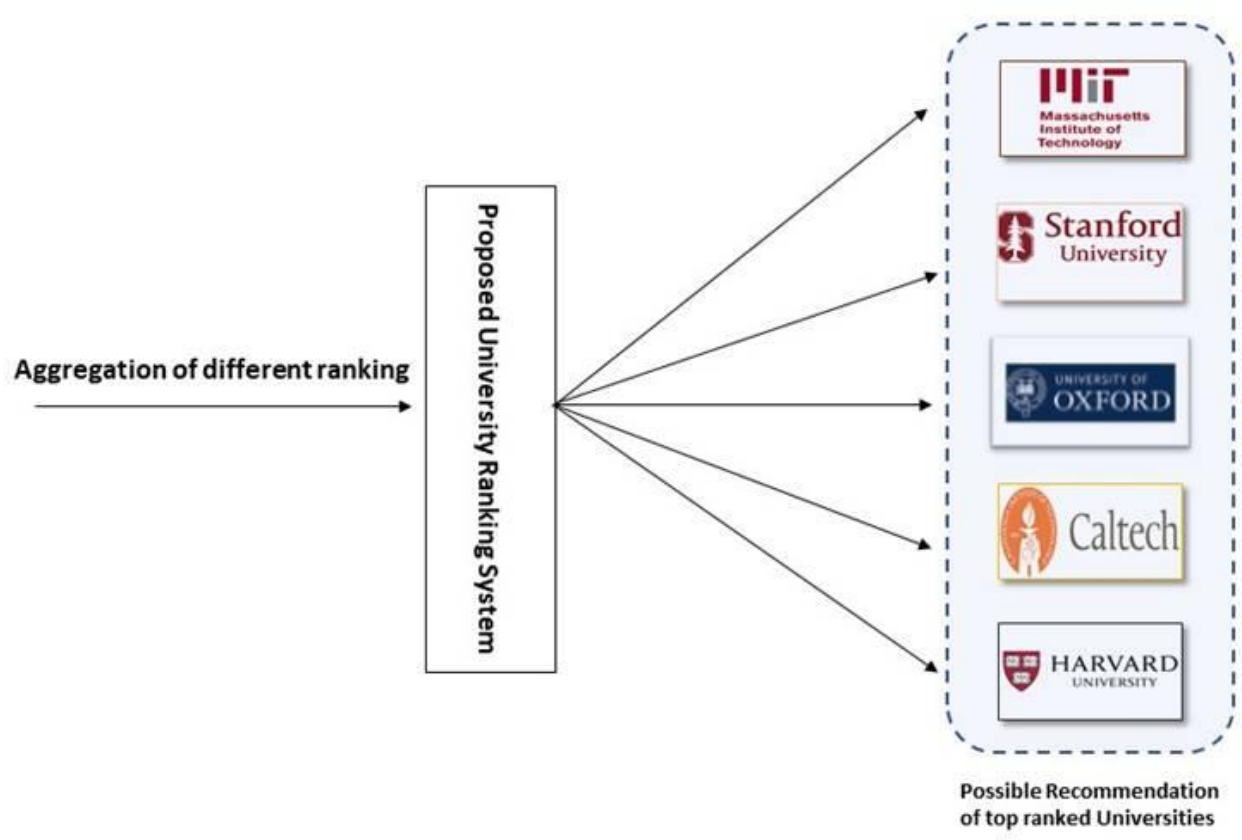

Figure 2: Possible Recommendation of Top Ranked Universities 
Table 3: Common criteria of different university ranking system according to [11][12][13][14][15] their weightage.

\begin{tabular}{llllll}
\hline Common Criteria & QS & THE & ARWU & RUR & U.S. NEWS \\
\hline Research & 0.2 & 0.48 & 0.4 & 0.4 & 0.625 \\
Teaching & 0.1 & 0.3 & 0.1 & 0.4 & 0 \\
Faculty & 0 & 0 & 0.4 & 0 & 0 \\
$\begin{array}{l}\text { International } \\
\text { Outlook }\end{array}$ & 0.1 & 0.075 & 0 & 0.1 & 0.1 \\
Reputation & 0.6 & 0 & 0 & 0 & 0.25 \\
\hline
\end{tabular}

\section{Conclusion}

In this paper, we depicted the framework of our proposed ranking system which incorporates the best features of the top-ranking system in the world.

We took the top five globally used ranking system namely QS, Times Higher Education, Round Ranking System, Academic Ranking of World Universities and U.S. News. These ranking approaches have various essential features like Research, Teaching, Faculty, International Outlook and Reputation. These features are common to all the above mentioned ranking approaches. By using these criteria, we built a framework for our new proposed ranking system. This ranking system of ours enables the aspirant students or scholars to get a much more refined result of universities to choose as it covers all the best possible features of the existing top university ranking approaches.

\section{References:}

[1] S.S. Sohail, J. Siddiqui, and R. Ali. "User feedback based evaluation of a product recommendation system using rank aggregation method." Advances in Intelligent Informatics. Springer, 2015. 349358.

[2] https://www.usnews.com/education/best-global-universities/rankings

[3] Marklein, Mary Beth. "Rankings create 'perverse incentives' - Hazelkorn". University World News. University World News. Retrieved 14 September 2016.

[4] http://roundranking.com/ranking/world-university-rankings.html\#world-2019

[5] Tilak JB. Global rankings, world-class universities and dilemma in higher education policy in India. Higher Education for the Future. 2016 Jul;3(2):126-43.

[6] https://en.wikipedia.org/wiki/Times_Higher_Education.

[7] S.S. Sohail, J. Siddiqui, and R. Ali. Product Recommendation Techniques for Ecommerce-past, present and future. International Journal of Advanced Research in Computer Engineering \& Technology (IJARCET), 2012. 1(9), 219.

[8] S.S. Sohail, J. Siddiqui, and R. Ali. Ordered ranked weighted aggregation based book recommendation technique: A link mining approach. In 2014 14th International Conference on Hybrid Intelligent Systems (pp. 309-314). IEEE. 
[9] https://en.wikipedia.org/wiki/Academic_Ranking_of_World_Universities

[10] https://en.wikipedia.org/wiki/Round_University_Ranking

[11] http://roundranking.com/methodology/methodology.html

[12] https://en.wikipedia.org/wiki/U.S._News_\%26_World_Report

[13] S.S. Sohail, J. Siddiqui, and R. Ali. An OWA-based ranking approach for university books recommendation. International Journal of Intelligent Systems, 2018. 33(2), pp.396-416.

[14] https://www.usnews.com/education/best-global-universities/articles/methodology

[15] https://www.topuniversities.com/university-rankings/world-university-rankings/2020

[16] https://www.timeshighereducation.com/world-university-rankings/2020/worldranking\#!/page/0/length/25/sort_by/rank/sort_order/asc/cols/stats

[17] http://www.shanghairanking.com/

[18] I. F Aguillo, J. Bar-Ilan, , M. Levene, and J. L. Ortega. Comparing university rankings. Scientometrics, 2010. 85(1), 243-256

[19] S.S. Sohail, J. Siddiqui, and R. Ali. Feature-Based Opinion Mining Approach (FOMA) for Improved Book Recommendation. Arabian Journal for Science and Engineering, 2018. 43(12), pp. 8029-8048.

[20] https://qswownews.com/history-development-higher-education-ranking-systems/. 